\title{
Structural basis for HIV-I DNA integration in the human genome
} Fabrice Michel ${ }^{1}$, Sylvia Eiler ${ }^{1}$, Florence Granger ${ }^{1}$, Jean-François Mouscadet ${ }^{2}$, Marina Gottikh', Alexis Nazabal ${ }^{4}$, Stéphane Emiliani ${ }^{5}$, Richard Benarous ${ }^{6}$, Dino Moras ${ }^{1}$, Patrick Schultz ${ }^{1}$ and Marc Ruff*1

Address: ${ }^{1}$ IGBMC, UDS, U596 Inserm, UMR7104 CNRS, 67404 Illkirch; France, ${ }^{2}$ Laboratoire de Biotechnologie et Pharmacologie Génétique Appliquée, CNRS, UMR8113, ENS-Cachan, 94235 Cachan, France, ${ }^{3}$ Belozersky Institute of Physico-Chemical Biology, Moscow State University, 119992 Moscow, Russia, ${ }^{4}$ CovalX, Technoparkstrasse, 1, CH-8005, Zürich, Zwitzerland, 5 Institut Cochin, Université Paris Descartes, CNRS (UMR8104), Inserm, U567, Paris, France and ${ }^{6}$ CellVir SAS, Evry, France; Hybrigenics SA, Paris, France

* Corresponding author

from Frontiers of Retrovirology: Complex retroviruses, retroelements and their hosts Montpellier, France. 21-23 September 2009

Published: 24 September 2009

Retrovirology 2009, 6(Suppl 2):P79 doi:10.1186/1742-4690-6-S2-P79

This abstract is available from: http://www.retrovirology.com/content/6/S2/P79

(c) 2009 Michel et al; licensee BioMed Central Ltd.

Integration of the human immunodeficiency virus type 1 (HIV-1) cDNA into the human genome is catalyzed by the viral integrase protein that requires the lens epitheliumderived growth factor (LEDGF), a cellular transcriptional coactivator. In the presence of LEDGF, integrase forms a stable complex in vitro and importantly becomes soluble by contrast with integrase alone which aggregates and precipitates. Using cryo-electron microscopy (EM) and single-particle reconstruction, we obtained threedimensional structures of the wild type full length integrase-LEDGF complex with and without DNA [1]. The stoichiometry of the complex was found to be (integrase) $4^{-}$ $(\text { LEDGF })_{2}$ by mass spectrometry analysis and existing atomic structures were unambiguous positioned in the EM map. In vitro functional assays reveal that LEDGF increases integrase activity likely in maintaining a stable and functional integrase structure. DNA-Protein crosslinking experiments show specific interaction between viral DNA and the C-terminal domain of integrase. Upon DNA binding, IN undergoes large conformational changes. Cryo-EM structure underlines the path of viral and target DNA and a model for DNA integration in human DNA is proposed (see fig. 1, overleaf). 


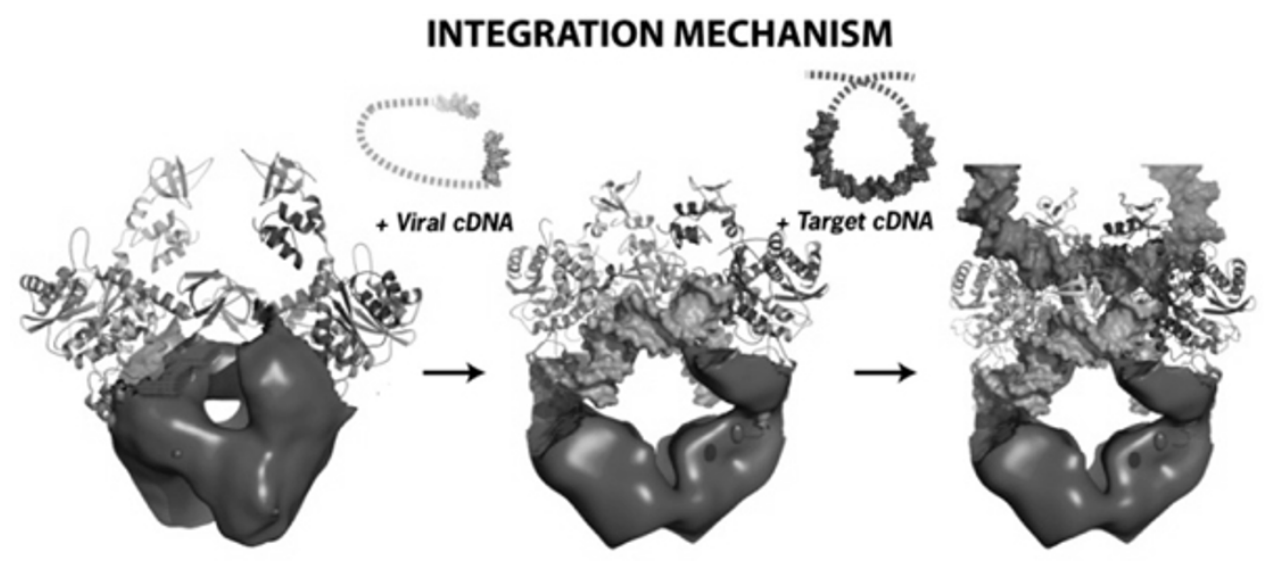

3' processing
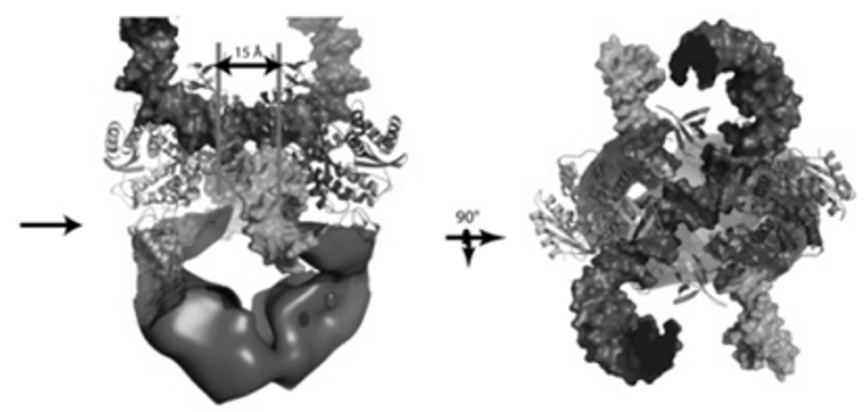

Integration

Figure I

Proposed mechanism for thei ntegration of viral CDNA into the host genome: The LEDGF envelope is represented in blue; the integrase tetramer is shown as atomic structures. The viral DNA is in orange and the target DNA in red. On target DNA binding, there is a conformational change of the integrase proteins to position the viral DNA for the integration within 5 bases pairs in the target DNA.

\section{References}

I. Michel F, Crucifix C, Granger F, Eiler S, Mouscadet JF, Korolev S, Agapkina J, Ziganshin R, Gottikh M, Nazabal A, Emiliani S, Benarous R, Moras D, Schultz P, Ruff M: Structural basis for HIV-I DNA integration in the human genome, role of the LEDGF/P75 cofactor. EMBO J 2009, 28:980-99I.

Publish with Biomed Central and every scientist can read your work free of charge

"BioMed Central will be the most significant development for disseminating the results of biomedical research in our lifetime."

Sir Paul Nurse, Cancer Research UK

Your research papers will be:

- available free of charge to the entire biomedical community

- peer reviewed and published immediately upon acceptance

- cited in PubMed and archived on PubMed Central

- yours - you keep the copyright
BioMedcentral 